\title{
Role of Solvability Ratio of Financial Performance at Pt. Orientama Lintas Buana
}

\author{
Riska Yulianti, Erry Rimawan, Cecep Hermawan, Febry Wonggiawan \\ Magister of Management ${ }^{1}$, Magister Industrial Engineering ${ }^{2,3,4}$ \\ Mercu Buana University, Jakarta State, Indonesia
}

\begin{abstract}
Financial performance of PT. Orientama Lintas Buana in the period 2014 to 2016 based on solvency ratio analysis experiencing instability financial performance and decline in operating profit. The formulation of the problem in this study is whether the instability of financial performance and the decrease in operating profit seen from the period 2014 to 2016 has an important role to the financial performance of the company. The result of the research shows that PT. Orientama Lintas Buana in general has a good financial performance when examined from asset quality where the debt ratio to corporate assets in 2015 decreased compared to 2014 and 2016 and debt ratio to corporate capital in 2015 decreased compared to 2014 and 2016. Performance corporate finance is less good when viewed from the ratio of operating profit to liabilities where from 2014 to 2016 this ratio has decreased, this condition shows the company has not been able to perform efficiency over the operational expenses are too large.
\end{abstract}

Keywords:- Financial report, Solvency Ratio, Financial Performance.

\section{INTRODUCTION}

From year to year the number of companies that stand up and join the Indonesian business world is increasing. These companies compete with each other to reach as many customers as possible, so that they can meet the demands of public consumption, achieve expansion goals, maintain the survival of the company and improve the company's financial performance. The higher the solvency ratio, the higher the risk of loss faced, but there is also a chance of getting a large profit. Conversely, if a company has a low solvency ratio, it certainly has a smaller risk of loss.

In this research, the solvency ratios that will be used are debt to asset ratio, debt to equity ratio, and operating income to liabilities ratio. Indeed, in general thinking, if sales or revenues increase, it is believed that the company's financial performance will also increase. But that thinking is not always true because there are still other factors that must be considered before assessing the extent of the company's performance, especially in financial terms.

In this research, author identify the problem that the instability of the company's financial performance seen from the period 2014 to 2016 based on the analysis of solvency ratios and there is a decrease in operating profit was seen from the period 2014 to 2016 based on an analysis of operating income to liabilities ratio.

\section{LITERATURE REVIEW}

\section{$>$ Financial statements}

(kasmir, 2015), financial statements are reports that show the company's financial condition at this time or in a certain period. (Wahyudiono, 2014), the purpose of financial statements is essentially to assist users in estimating the company's future by comparing, evaluating, and analyzing trends from various aspects of corporate finance.

(Handono, 2012), there are three types in financial statements, including:

\section{- Income Statement}

Reports that show the company's operations in a certain period are divided into two main sections. First, income, which includes operating income (derived from sales activities) and non-operating income (for example, proceeds from sale of fixed assets).

\section{- Balance Sheet}

Reports that reveal the financial position (wealth) of a company on a certain date include assets, debt and equity.

\section{> Financial Ratio Analysis}

(kasmir, 2015), financial ratio analysis is an activity comparing the numbers in the financial statements by dividing one number with another number. (Irham, 2013), by comparing financial ratios from year to year the composition of changes can be studied and can be determined whether there is an increase or decrease in the condition and performance of the company during that time.

(Toto, 2014), the types of financial ratios are as follows:

- Activity $\rightarrow$ Ratio to measure the effectiveness of the company in turning around funds.

- Liquidity $\rightarrow$ Ratio to measure the company's ability to meet short-term obligations.

- Profitability $\rightarrow$ Ratio to measure the company's ability to generate profits.

- Solvency $\rightarrow$ Ratio to measure the company's ability to fulfill all obligations, both short and long term obligations.

- Market Measure $\rightarrow$ This ratio links the company's internal conditions with market perception. 


\section{Solvency Ratio}

(kasmir, 2015), solvency ratios or leverage ratios are ratios used to measure the extent to which a company's assets are financed with debt. (Irham, 2013), solvency ratios in general there are 4 namely debt to total assets ratio, debt to equity ratio, time interest earned ratio, longterm debt to equity ratio.

\section{Financial performance}

(Mulyadi, 2012), financial performance is a periodic determination of the operational effectiveness of an organization and its employees based on predetermined targets, standards and criteria. (Jumingan, 2013), performance measurement is used by companies to make improvements over their operational activities in order to compete with other companies. (Dr. Sumninder and Samiya, 2013), performance of companies can affect economy as a whole and therefore it requires empirical analysis to judge the performance. For measuring financial performance, financial ratios such as current ratio, solvency ratio, return on assets ratio and insurance leverage ratio have been calculated.

\section{METHODOLOGY}

\section{Population and Sample}

The sampling technique used is by taking research objects that meet the criteria, where the criteria are made by the author himself. The criteria that are sampled in this study are:

- Data on the company's financial statements which include the Balance Sheet and Income Statement for the 2014-2016 period.

- Interview company employees / staff directly related to research (Finance and Accounting).

\section{Observation Report Notes}

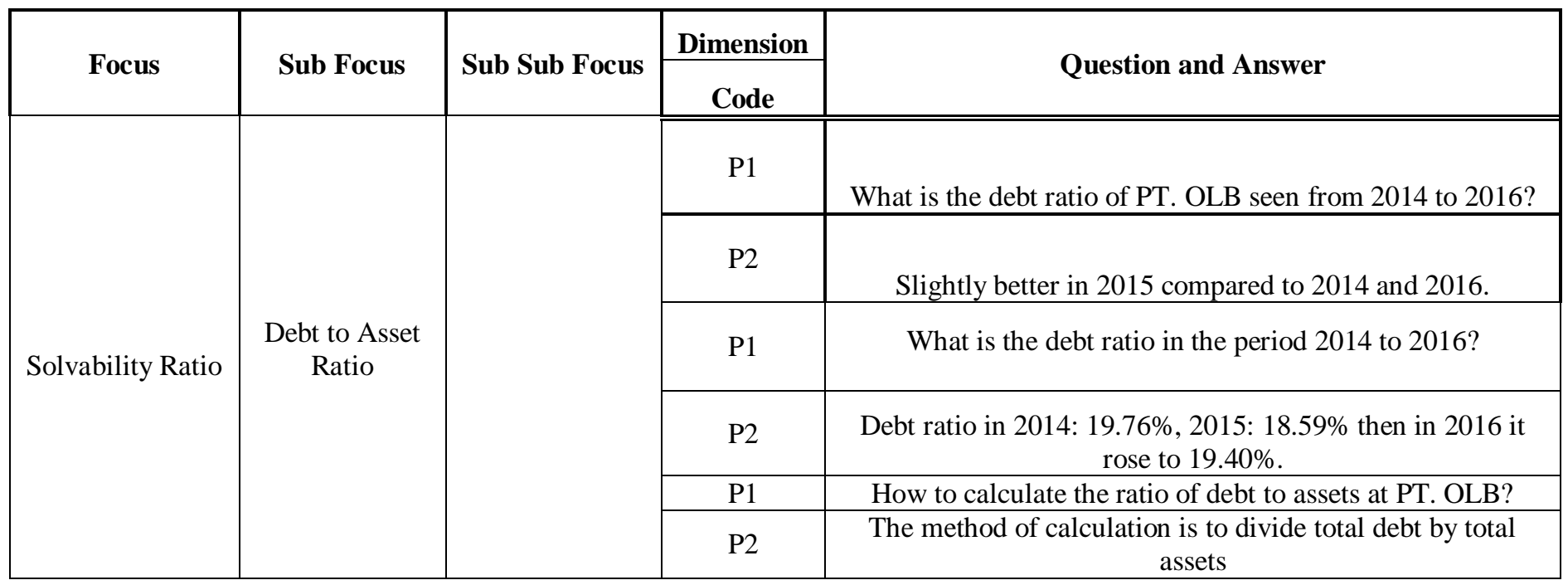

Table 1

\begin{tabular}{|c|c|c|c|c|}
\hline \multirow{2}{*}{ Focus } & \multirow{2}{*}{ Sub Focus } & \multirow{2}{*}{$\begin{array}{l}\text { Sub Sub } \\
\text { Focus }\end{array}$} & Dimension & \multirow{2}{*}{ Question and Answer } \\
\hline & & & Code & \\
\hline \multirow{6}{*}{ Solvability Ratio } & \multirow{6}{*}{$\begin{array}{l}\text { Debt to Equity } \\
\quad \text { Ratio }\end{array}$} & & $\mathrm{P} 1$ & $\begin{array}{l}\text { What is the debt to capital ratio of PT. OLB seen from } 2014 \\
\text { to } 2016 ?\end{array}$ \\
\hline & & & $\mathrm{P} 2$ & Slightly better in 2015 compared to 2014 and 2016. \\
\hline & & & $\mathrm{P} 1$ & What is the debt ratio in the period 2014 to $2016 ?$ \\
\hline & & & $\mathrm{P} 2$ & $\begin{array}{c}\text { Debt ratio in 2014: } 0.25,2015: 0.23 \text { then in } 2016 \text { it } \\
\text { increased again to } 0.25\end{array}$ \\
\hline & & & $\mathrm{P} 1$ & How to calculate the ratio of debt to capital at PT. OLB? \\
\hline & & & $\mathrm{P} 2$ & $\begin{array}{l}\text { The method of calculation is to divide total debt by total } \\
\text { capital }\end{array}$ \\
\hline
\end{tabular}


ISSN No:-2456-2165

\begin{tabular}{|c|c|c|c|c|}
\hline \multirow[t]{2}{*}{ Focus } & \multirow[t]{2}{*}{ Sub Focus } & \multirow[t]{2}{*}{ Sub Sub Focus } & Dimension & \multirow[t]{2}{*}{ Question and Answer } \\
\hline & & & Code & \\
\hline \multirow{6}{*}{ Solvability Ratio } & \multirow{6}{*}{$\begin{array}{l}\text { Ratio of } \\
\text { Operating } \\
\text { Profit to } \\
\text { Liability }\end{array}$} & & $\mathrm{P} 1$ & $\begin{array}{l}\text { How is the ratio of operating profit to the } \\
\text { obligations of PT. OLB seen from } 2014 \text { to } 2016 ?\end{array}$ \\
\hline & & & $\mathrm{P} 2$ & $\begin{array}{l}\text { In } 2015 \text { and 2016, it is no better than the ability } \\
\text { of operating profit to pay obligations in } 2014\end{array}$ \\
\hline & & & $\mathrm{P} 1$ & $\begin{array}{l}\text { What is the ratio of operating income to } \\
\text { liabilities in the period } 2014 \text { to } 2016 ?\end{array}$ \\
\hline & & & $\mathrm{P} 2$ & $\begin{array}{l}\text { The ratio of operating income to liabilities in } \\
\text { 2014: } 1.40 \text {, in } 2015: 0.80 \text {, then in } 2016 \text { the } \\
\text { decline was } 0.68\end{array}$ \\
\hline & & & $\mathrm{P} 1$ & $\begin{array}{c}\text { The ratio of operating income to liabilities in } \\
\text { 2014: } 1.40 \text {, in 2015: } 0.80 \text {, then in } 2016 \text { the } \\
\text { decline was } 0.68\end{array}$ \\
\hline & & & $\mathrm{P} 2$ & $\begin{array}{l}\text { The method of calculation is to divide operating } \\
\text { income with total liabilities }\end{array}$ \\
\hline
\end{tabular}

Table 3

\begin{tabular}{|c|c|c|c|c|}
\hline \multirow{2}{*}{ Focus } & \multirow{2}{*}{ Sub Focus } & \multirow{2}{*}{ Sub Sub Focus } & Dimension & \multirow{2}{*}{ Question and Answer } \\
\hline & & & Code & \\
\hline \multirow{6}{*}{$\begin{array}{l}\text { Financial } \\
\text { Performance }\end{array}$} & \multirow{6}{*}{$\begin{array}{l}\text { Measurement } \\
\text { of Financial } \\
\text { Performance }\end{array}$} & & $\mathrm{P} 1$ & $\begin{array}{c}\text { What is the purpose of PT. Does OLB measure financial } \\
\text { performance? }\end{array}$ \\
\hline & & & $\mathrm{P} 2$ & $\begin{array}{l}\text { To make improvements over operational activities in order } \\
\text { to compete with other companies }\end{array}$ \\
\hline & & & P1 & $\begin{array}{l}\text { Is the measurement of financial performance at PT. Can } \\
\text { OLB influence the behavior of decision making? }\end{array}$ \\
\hline & & & $\mathrm{P} 2$ & Yes, very influential \\
\hline & & & $\mathrm{P} 1$ & $\begin{array}{l}\text { Is the performance assessment of PT. OLB is the same as } \\
\text { other companies? }\end{array}$ \\
\hline & & & $\mathrm{P} 2$ & $\begin{array}{l}\text { Certainly different because it depends on the scope of the } \\
\text { business being run }\end{array}$ \\
\hline
\end{tabular}

Table 4

\begin{tabular}{|c|c|c|c|c|}
\hline Focus & Sub Focus & Sub Sub Focus & Dimension & Question and Answer \\
\hline \hline & & & Code & P1 \\
\cline { 5 - 5 } $\begin{array}{c}\text { Financial } \\
\text { Performance }\end{array}$ & $\begin{array}{c}\text { Analyzing } \\
\text { Financial } \\
\text { Performance }\end{array}$ & & What is the stage in analyzing financial performance at PT. \\
OLB?
\end{tabular}


ISSN No:-2456-2165

\begin{tabular}{|c|c|c|c|c|}
\hline \multirow{2}{*}{ Focus } & \multirow{2}{*}{ Sub Focus } & \multirow{2}{*}{ Sub Sub Focus } & Dimension & \multirow{2}{*}{ Question and Answer } \\
\hline & & & Code & \\
\hline \multirow{7}{*}{$\begin{array}{l}\text { Financial } \\
\text { Performance }\end{array}$} & \multirow{7}{*}{$\begin{array}{l}\text { Relationship } \\
\text { of Financial } \\
\text { Performance } \\
\text { and Financial } \\
\text { Ratios }\end{array}$} & & $\mathrm{P} 1$ & $\begin{array}{l}\text { What is used by PT. OLB to assess the condition and } \\
\text { financial performance of the company? }\end{array}$ \\
\hline & & & $\mathrm{P} 2$ & $\begin{array}{l}\text { Use ratios and compare figures contained in financial } \\
\text { statement items }\end{array}$ \\
\hline & & & $\mathrm{P} 1$ & $\begin{array}{l}\text { What are the benefits of PT. OLB by using financial ratio } \\
\text { analysis? }\end{array}$ \\
\hline & & & & \\
\hline & & & $\mathrm{P} 2$ & $\begin{array}{l}\text { PT. OLB can plan and manage all the needs of the company } \\
\text { to measure the strengths and weaknesses in achieving and } \\
\text { improving what the company aspires }\end{array}$ \\
\hline & & & $\mathrm{P} 1$ & $\begin{array}{l}\text { What makes PT. OLB difficulties in calculating financial } \\
\text { ratios? }\end{array}$ \\
\hline & & & $\mathrm{P} 2$ & if the data available is out of sync, it will be difficult \\
\hline
\end{tabular}

\section{Data Collection Instruments}

In terms of collecting data that has been obtained for the writing of this thesis proposal, the writer obtains data from various sources, namely:

\section{- Field Research}

This study looks for data directly from the object under study, so the results can be trusted. The method adopted is through:

$\checkmark$ Interview $\rightarrow$ namely a data collection technique by means of question and answer with authorized officials or other sections directly related to the research, namely at the Department of Finance Accounting PT. Orientama Lintas Buana. The author collects data about PT. Orientama Lintas Buana to get an overview and specific problems under study. The data obtained is expected to explain the role of the solvency ratio to the company's financial performance.

$\checkmark$ Observation $\rightarrow$ is a data collection technique that is done by observing directly the activities of the office of PT. Orientama Lintas Buana is closely related to the documents needed. The data collected is a financial statement consisting of a balance sheet and income statement at PT. Orientama Lintas Buana.

\section{- Literature Research}

Literature study is conducted to obtain information and secondary data. Done through the review and study of literature, regulations, documents and other sources relevant to the issues discussed in the study. For example, the authors study the company's financial performance books, solvency ratios, financial reports and analysis of financial ratios related to research.

\section{Research Data Analysis}

Analysis of the data used in this study is the qualitative data model of Miles and Huberman which suggests that the activities in qualitative data analysis are carried out interactively and continue continuously until it is complete so that the data is saturated. Activities in this analysis consist of three activities that occur simultaneously, namely data reduction, data presentation, drawing conclusions / verification. Analysis

(Miles and Huberman, 2014), Qualitative Data 


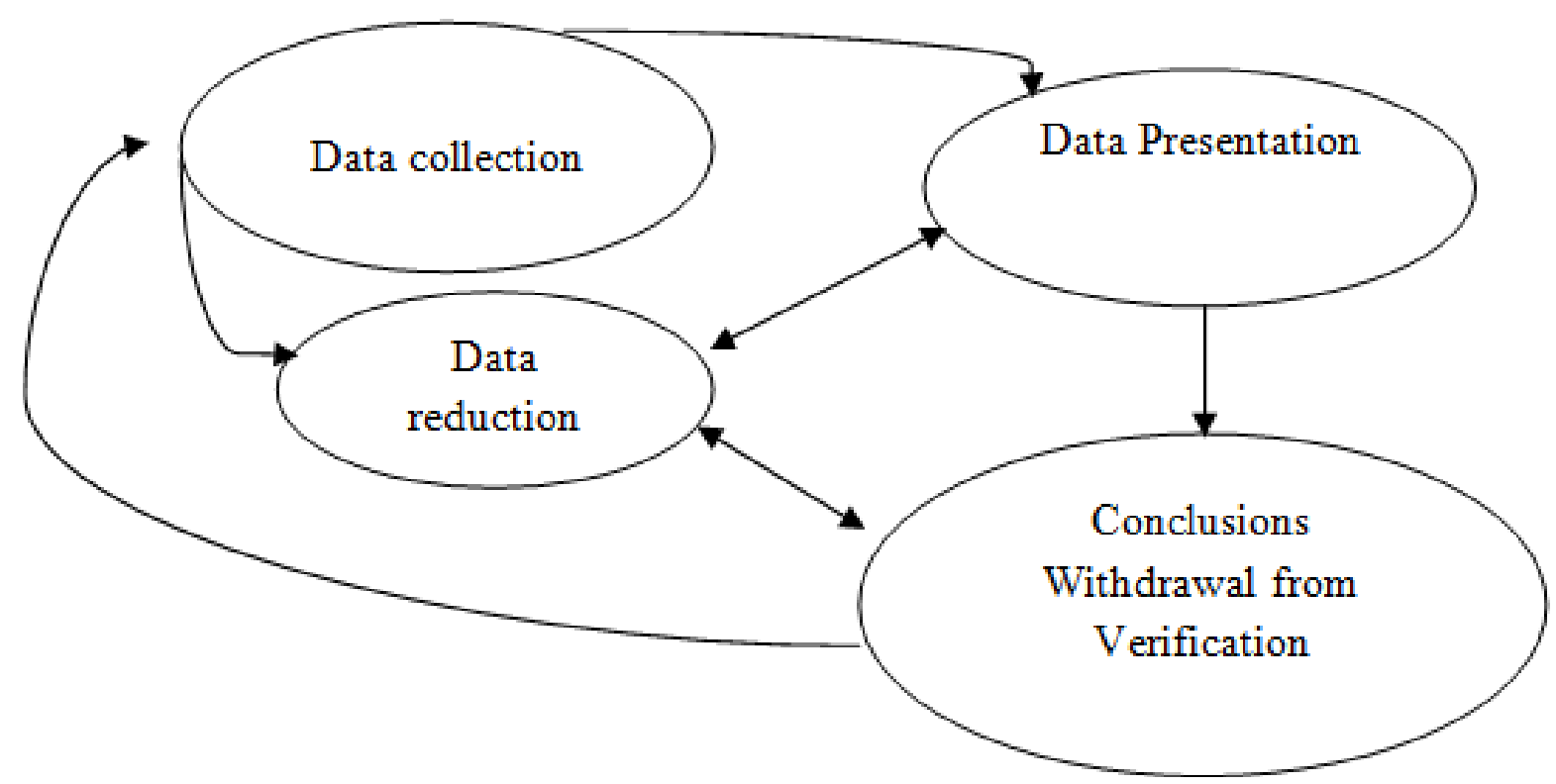

Fig 1

IV. RESULT

\section{Debt to Asset Ratio}

The following is a graph of the ratio of debt to assets:

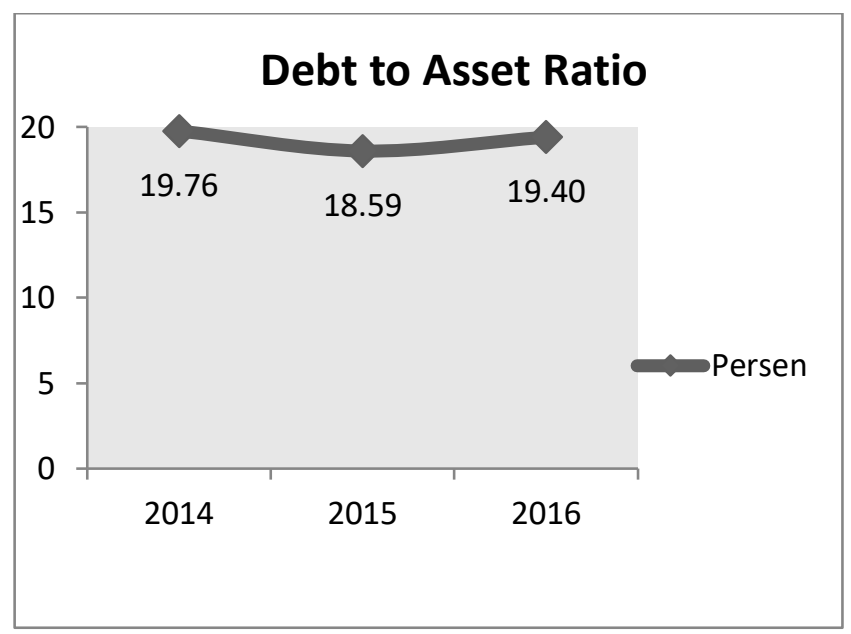

Fig 2

Based on the graph above, it can be seen that the movement of debt to asset ratio of PT. Orientama Lintas Buana from 2014 to 2016 shows a movement that tends to decrease from $19.76 \%$ to $19.40 \%$, this is because the total increase in total debt from 2014-2016 is smaller than the total increase in total assets. This condition shows the burden borne by the company in fulfilling long-term obligations by using all of its wealth is decreasing.

So it appears that the company's debt to asset ratio in 2015 has decreased compared to 2014 and 2016. Because the lower the ratio the better, the greater the protection against creditors' losses in the event of liquidation.

\section{Debt to Equity Ratio}

The following is a graph of the ratio of debt to assets:

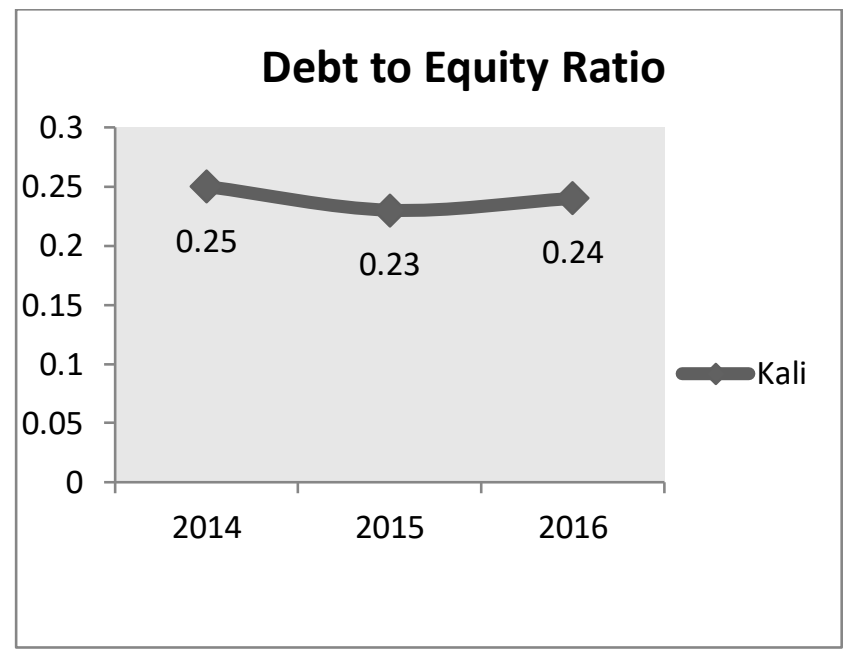

Fig 3

Based on the graph above, it can be seen that the movement of debt to equity ratio of PT. Orientama Lintas Buana from 2014 to 2016 shows a movement that tends to decrease from 0.25 times to 0.24 times, this is because the amount of increase in total debt from 2014-2016 is smaller than the amount of increase in total capital. This condition shows that the burden borne by the company in fulfilling its obligations using its own capital is decreasing.

So it appears that the company's debt to equity ratio in 2015 has decreased when compared to 2014 and 2016 because the amount of company capital in 2015 that can be used as collateral for debt is greater than the amount of company capital in 2014 and 2016. 
Operating Income To Liabilities Ratio

The following is a graph of the ratio of debt to

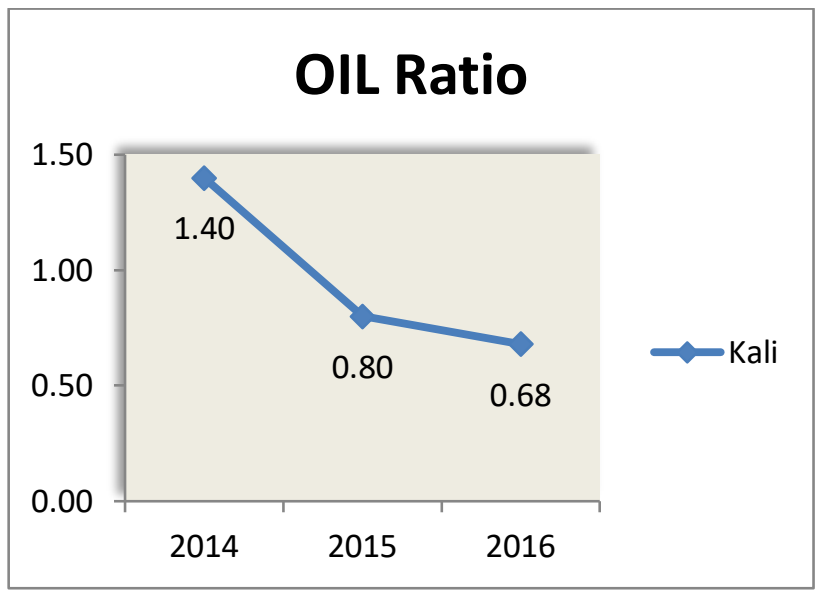

Fig 4

Based on the graph above, it can be seen that the movement of operating income to liabilities ratio of PT. Orientama Lintas Buana from 2014 to 2016 showed a downward movement from 1.40 times to 0.68 times, this is because the amount of increase in operating profit in 2015 and 2016 was smaller than the total increase in total liabilities. This condition shows the company's ability to pay off its obligations with operational profit is decreasing.

From these data it can be seen that the operating income to liabilities ratio in 2014 is better than the operating income to liabilities ratio in 2015 and 2016. The greater this ratio is the better because it shows the company's ability to pay its obligations with operating profit.

\section{CONCLUSIONS}

Based on the analysis and discussion in this research, financial performance of PT. Orientama Lintas Buana during 2014-2016 showed quite good financial performance and the role of solvency ratios greatly influenced the company's financial performance.

$>$ In the debt to asset ratio, seen from 2014 to 2016 in general the financial performance of PT. Orientama Lintas Buana is in good condition, which indicates that the greater protection against creditors' losses in the event of liquidation.

In the debt to equity ratio, seen from 2014 to 2016 can be said to be in a stable state, because the amount of capital of PT. Orientama Lintas Buana in 2015 was larger so that it could be used as a debt collateral.

$>$ In the operating income to liabilities ratio, seen from 2014 to 2016 can be said to be in a state of decline, except in 2014 where PT. Orientama Lintas Buana can generate sizable profits.

\section{REFERENCES}

[1]. Dr. Sumninder and Samiya. (2013). Financial Performance of Life Insurers in Indian Insuranc. Pacific Business Review International, 6(5), 51. http://poster.pacificuniversity.ac.in/2013/2013_month/Nov/7.pdf

[2]. Handono. (2012). Intisari Manajemen Keuangan. Grasindo.

[3]. Irham. (2013). Analisis Laporan Keuangan. Alfabeta cv.

[4]. Jumingan. (2013). Analisis Laporan Keuangan. PT. Bumi Aksara.

[5]. kasmir. (2015). Analisis Laporan Keuangan. Rajawali Pers.

[6]. Miles and Huberman. (2014). Analisis Data Kualitatif. UIP.

[7]. Mulyadi. (2012). Akuntansi Keuangan. Salemba Empat.

[8]. Toto. (2014). Deteksi Cepat Kondisi Keuangan: 7 Analisis Rasio Keuangan. PPM Manajemen.

[9]. Wahyudiono. (2014). Mudah Membaca Laporan Keuangan. Raih Asa Sukses. 